\title{
ANALISIS KUALITAS PELAYANAN DENGAN MENGGUNAKAN QUALITY FUNCTION DEPLOYMENT PADA MODERN LAUNDRY CIREBON
}

\author{
Roby Sentosa ${ }^{1}$, Laura Lahindah ${ }^{2}$, Linda Gandajaya ${ }^{3}$ \\ Departemen Manajemen \\ Sekolah Tinggi Ilmu Ekonomi Harapan Bangsa, Bandung
}

\begin{abstract}
Service Quality has a close relationship with customer satisfaction. Service quality provides encouragement to customers to establish strong ties with the company. Customer satisfaction is created if customer's needs or expectations can be met through the quality of services provided. The good or bad quality of the service depends on the ability of the service providers to consistently meet customer's needs or expectations. The research was conducted on a business unit that offered services in the case of perkilogram clothes washing, namely Modern Laundry. As a business unit that has a mature age, Modern Laundry must be able to know and make services that are needed and demanded by its customers. To be able to do it, a method is needed in this study. The method used in this study is QFD (Quality Function Deployment). The QFD method provides technical requirements by meeting the customer's voice with the company's voice. With the use of this method, companies are able to find out what is the customer's needs and demand, what services must be maintained, improved and eliminated. This study tested the validity and reliability so that the data used in this study were valid and reliable. The results of this study are there are several characteristics of customer needs and desires that must be prioritized by Moden Laundry. Not only these characteristics in this study the technical characteristics that need to be prioritized also by Modern Laundry.

Keywords $\quad$ : Customer Satisfaction, Service Quality, Quality Function Deployment
\end{abstract}

\begin{abstract}
ABSTRAK
Kualitas Pelayanan memiliki hubungan yang erat dengan kepuasan pelanggan. Kualitas pelayanan memberikan suatu dorongan kepada pelanggan untuk menjalin ikatan yang kuat dengan perusahaan. Kepuasan pelanggan tercipta jika kebutuhan atau harapan pelanggan dapat terpenuhi melalui kualitas pelayanan yang diberikan. Baik buruknya kualitas pelayanan tergantung pada kemampuan penyedia jasa untuk memenuhi kebutuhan atau harapan pelanggan secara konsisten. Penelitian dilakukan pada suatu unit bisnis yang menawarkan jasa dalam hal pencucian pakaian kiloan yaitu Modern Laundry. Sebagai unit bisnis yang tergolong ke dalam usia yang matang maka Modern Laundry harus dapat mengetahui dan membuat layanan yang dibutuhkan dan diinginkan oleh pelanggan. Untuk dapat melaksanakan hal tersebut maka diperlukan sebuah metode didalam penelitian ini. Metode yang digunakan dalam penelitian ini adalah QFD (Quality Function Deployment). Metode QFD memberikan persyaratan teknis dengan mempertemukan suara pelanggan dengan suara perusahaan. Dengan digunakannya metode ini, perusahaan mampu mengetahui apa saja yang menjadi kebutuhan dan keinginan pelanggan, pelayanan apa saja yang harus dipertahankan, ditingkatkan dan ditiadakan. Penelitian ini melakukan uji validitas dan reliabilitas sehingga data-data yang digunakan dalam penelitian ini valid dan reliabel. Hasil dari penelitian menunjukkan beberapa persyaratan pelanggan yang dinilai penting oleh pelanggan, beberapa persyaratan teknis yang diterjemahkan untuk memenuhi persyaratan pelanggan, penilaian pelanggan terhadap Modern Laundry dan karakteristik kualitas pelayanan yang harus ditingkatkan oleh Modern Laundry. Dengan memperhatikan hal tersebut, maka Modern Laundry dapat meningkatkan kualitas pelayanannya untuk memenuhi kebutuhan pelanggannya.

Kata Kunci : Kepuasan Pelanggan, Kualitas Pelayanan, Quality Function Deployment
\end{abstract}




\section{PENDAHULUAN}

Pertumbuhan bisnis Laundry di Indonesia mengalami perkembangan yang cukup signifikan. Jika dahulu bisnis tersebut hanya berkembang di kota-kota besar saja, namun saat ini mulai marak juga di beberapa pelosok daerah. Fasilitas dan pelayanan yang ditawarkannya pun beragam, seperti waktu pencucian yang lebih cepat maupun adanya jasa delivery. Perubahan gaya hidup masyarakat yang menginginkan semuanya menjadi serba praktis khususnya dalam hal mencuci pakaian membuat jasa Laundry menjadi suatu alternatif pilihan dibandingkan mencuci sendiri. Perubahan gaya hidup tersebut menjadi salah satu faktor yang mendorong bisnis Laundry semakin marak dan menjadi lebih menjanjikan untuk kedepannya.

Modern Laundry adalah sebuah badan usaha yang menawarkan jasa dalam hal pencucian pakaian kiloan yang tergolong kedalam UMKM (Usaha Mikro Kecil dan Menengah). Layanan yang diberikan pun cukup beragam, seperti adanya jasa antar-jemput pakaian bagi para pelanggannya, dilakukannya klasifikasi pakaian berdasarkan kepemilikan sehingga mengurangi pakaian tertukar dan pelanggan dapat memilih kapan waktu pencucian tersebut dapat diselesaikan. Keberagaman layanan tersebut diberikan mengingat semakin maraknya bisnis usaha Laundry di Kota Cirebon khususnya yang berada di Kecamatan Pekalipan. Data usaha Laundry tersebut dapat dilihat pada tabel 1 di bawah ini:

Tabel 1. Daftar Usaha Laundry di Kecamatan Pekalipan Cirebon

\begin{tabular}{|l|l|c|l|}
\hline No. & Nama Usaha Laundry & Tahun Berdiri & \multicolumn{1}{|c|}{ Alamat } \\
\hline 1 & Max Coin Laundry & 2015 & Jalan Petratean No.41 \\
\hline 2 & Modern Laundry & 1976 & Jalan Petratean No.72 \\
\hline 3 & Orchid Laundry & 2013 & Jalan Kebon Cai No.37 \\
\hline 4 & Spin Laundry & 2001 & Jalan Arya Kemuning No.98a \\
\hline 5 & Agen Angkasa Laundry & 1998 & Jalan Kesambi Dalam \\
\hline
\end{tabular}

Sumber : Hasil Observasi Peneliti (2018)

Berdasarkan wawancara yang dilakukan di lapangan kepada pemilik Modern Laundry, pemilik mengeluhkan adanya fluktuasi jumlah pelanggan yang cukup signifikan dalam satu tahun terakhir dan kemudian mengalami penurunan yang cukup signifikan. Melalui wawancara tersebut, diperoleh data jumlah pelanggan yang berasal dari pihak Modern Laundry. Berdasarkan data yang diperoleh tersebut dapat terlihat jelas bagaimana fluktuasi dan jumlah pelanggan semakin menurun selama satu tahun terakhir, tepatnya pada periode bulan Juli 2017 sampai bulan Juli 2018. Untuk lebih jelasnya dapat dilihat pada gambar 1 . berikut:

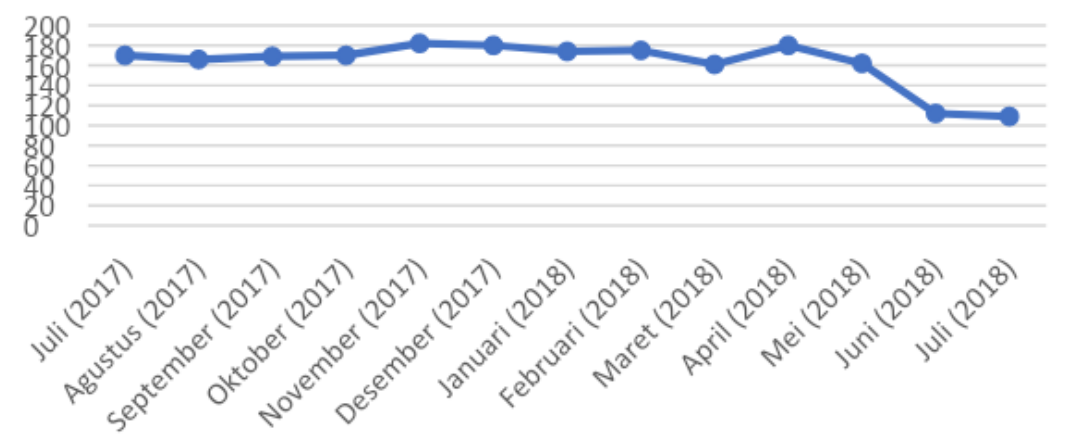

Gambar 1. Jumlah Pelanggan Modern Laundry CirebonTahun 2017-2018 Sumber : Modern Laundry (2018) 
Masalah lain yang terjadi adalah data keluhan pelanggan yang cenderung meningkat. Peningkatan jumlah keluhan pelanggan tersebut dapat lebih jelas dilihat pada gambar 1 dibawah ini:

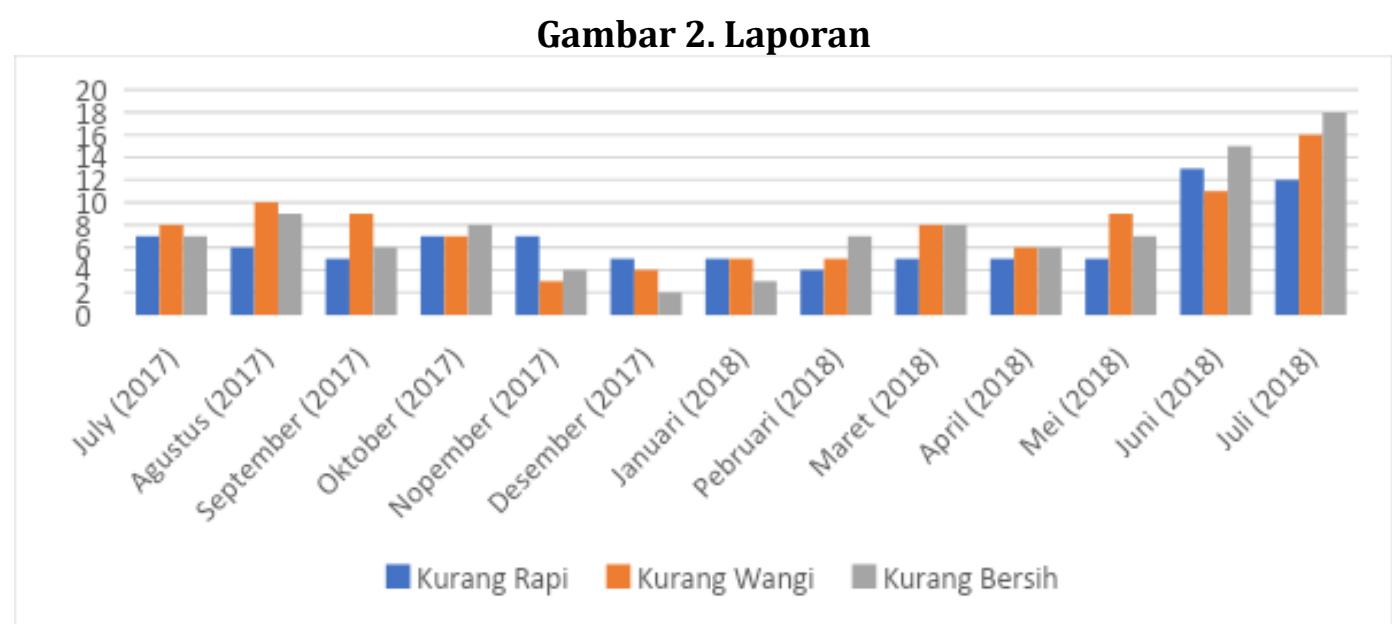

\section{Keluhan Pelanggan Modern Laundry Cirebon Sumber: Modern Laundry (2018)}

Berdasarkan gambar 2. diketahui bahwa laporan keluhan pelanggan mengalami kenaikan yang cukup besar pada 2 bulan terakhir yaitu Juni dan Juli tahun 2018. Pelanggan banyak mengeluhkan akan kerapihan dari pakaian yang disetrika, wangi dari pakaian yang di cuci dan kebersihan dari pakaian yang di cuci. Keluhan pelanggan tentang ketiga hal tersebut diduga erat kaitannya dengan kualitas pelayanan pada Modern Laundry yang berdampak pada penurunan jumlah pelanggannya. Kualitas merupakan suatu kondisi dinamis yang berhubungan dengan produk, jasa, manusia, proses, dan lingkungan yang memenuhi atau melebihi harapan (Tjiptono \& Chandra, 2016). Kualitas pelayanan adalah setiap tindakan atau kegiatan yang dapat ditawarkan oleh satu pihak kepada pihak lain, pada dasarnya tidak berwujud ditawarkan oleh satu pihak kepada pihak lain, pada dasarnya tidak berwujud dan tidak mengakibatkan perpindahan kepemilikan apapun (Kotler, 2013).

Kualitas memiliki hubungan yang erat dengan kepuasan pelanggan. Kualitas memberikan suatu dorongan kepada pelanggan untuk menjalin ikatan yang kuat dengan perusahaan. Kualitas pelayanan sebagai tingkat keunggulan yang diharapkan dan pengendalian atas tingkat keunggulan tersebut untuk memenuhi keinginan pelanggan (Parasuraman, 2013). Untuk meningkatkan kualitas pelayanan didalam perusahaan dapat menggunakan Total Quality Management (TQM). TQM adalah aktivitas seluruh organisasi yang dirancang untuk meningkatkan semua dimensi kualitas produk dan jasa yang penting bagi pelanggan (Heizer, Render, \& Munson, 2017).

Salah satu metode TQM yang digunakan adalah Quality Function Deployment (QFD). QFD merujuk pada (1) menentukan apa yang akan memuaskan pelanggan dan (2) menerjemahkan keinginan pelanggan ke dalam target desain (Heizer, Render, \& Munson, 2017). QFD memiliki alat bantu yang disebut House of Quality (HoQ). HoQ adalah bagian dari QFD yang memanfaatkan matriks perencanaan untuk menghubungkan keinginan pelanggan dengan cara yang dilakukan perusahaan dalam memenuhi keinginan tersebut (Heizer, Render, \& Munson, 2017). Intinya adalah memenangkan pemahaman yang baik atas keinginan pelanggan dan mengidentifikasi solusi proses alternatif. QFD digunakan pada awal proses untuk membantu menentukan apa yang kan memuaskan pelanggan dan dimana upaya penyebaran kualitas dibutuhkan (Heizer \& Render, 2014).

QFD merupakan suatu proses atau mekanisme untuk menentukan kebutuhan pelanggan dan menterjemahkan kebutuhan-kebutuhan itu kedalam kebutuhan teknis yang relevan, di mana masing- 
masing area fungsional dan tingkat organisasi dapat mengerti dan bertindak (Dharmawan \& Wurjaningrum, 2014). Menurut (Cohen, 2010) House of Quality terdiri dari 8 bagian, dimana tiap bagiannya memiliki arti yang berbeda-beda, penjelasannya sebagai berikut:

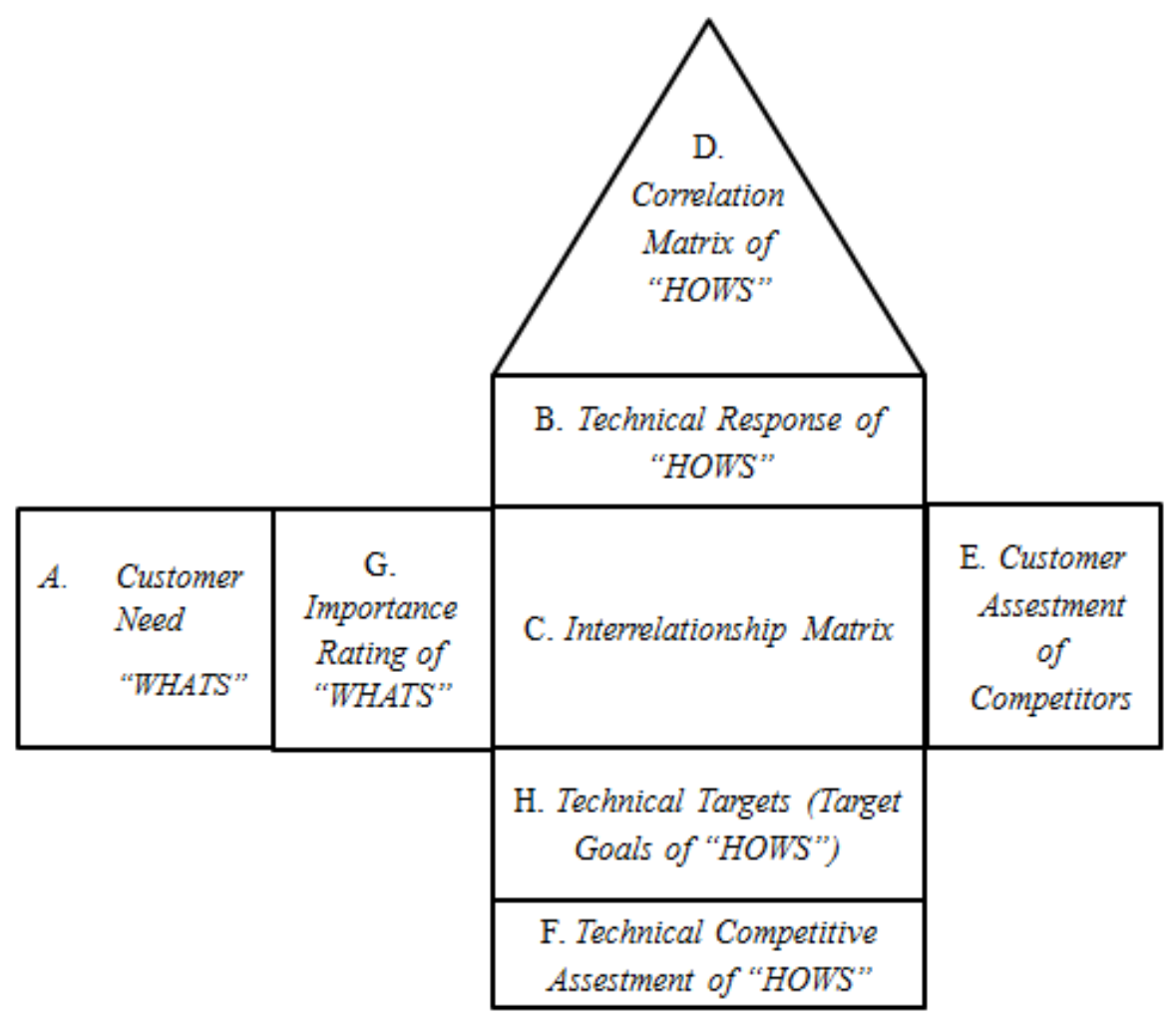

Gambar 3 Struktur House of Quality

Sumber: (Cohen, 2010)

1. Bagian A: Berisi tentang masukan dari pelanggan yang diperoleh melalui kuesioner penelitian tentang daftar kebutuhan dan keinginan pelanggan.

2. Bagian B: Berdasarkan data yang diperoleh dari Bagian A, perusahaan menentukan karakteritsik teknis yang akan dibuat untuk memenuhi kebutuhan dan keinginan pelanggan.

3. Bagian C: Menggambarkan hubungan antara karakteristik kebutuhan dan keinginan pelanggan (Bagian A) dengan karakteristik teknis perusahaan (Bagian B).

4. Bagian D: Menentukan hubungan antar karakteristik teknis perusahaan. Berkorelasi positif atau negatif.

5. Bagian E: Menggambarkan hasil penilaian akan daya saing yang dimiliki perusahaan jika dibandingkan dengan kompetitor atau pesaingnya. Penilaian tersebut dirangking berdasarkan kebutuhan dan keinginan pelanggan (A).

6. Bagian F: Menggambarkan hasil penilaian akan daya saing yang dimiliki perusahaan jika dibandingkan pesaingnya. Penilaian tersebut diranking berdasarkan karakteristik teknis perusahaan (B).

7. Bagian G: Mengidentifikasi tingkat kepentingan konsumen untuk setiap karakteristik kebutuhan konsumen yang diperoleh.

8. Bagian H: Menentukan nilai target perusahaan dari hasil evaluasi karakteristik teknis perusahaan (B).

Terdapat lima dimensi kualitas pelayanan (jasa) yang dapat digunakan untuk mengukur kualitas dari sebuah perusahaan jasa (Krajewski, Ritzman, \& Malhotra, 2010), yaitu: 
1. Reliability: Kemampuan untuk memberikan layanan sesuai dengan yang dijanjijkan dengan andal dan akurat.

2. Assurance: Pengetahuan dan kesopanan karyawan dan kemampuan mereka untuk meningkatkan kepercayaan dan keyakinan konsumen.

3. Tangibles: Fasilitas fisik, peralatan, dan penampilan personel.

4. Empathy: Perhatian individual perusahaan kepada pelanggannya.

5. Responsiveness: Kesediaan membantu pelangggan dengan cepat.

Melalui pembuatan House of Quality akan diperoleh informasi yang berguna untuk dianalisa dari sudut karakteristik kebutuhan dan keinginan pelanggan serta karakteristik teknis perusahaan. Hasil dari analisa tersebut diharapkan dapat dijadikan masukan yang bermanfaat untuk Modern Laundry dalam meningkatkan kualitas pelayanannya.

Penelitian ini bertujuan untuk meningkatkan kualitas pelayanan pada Modern Laundry, adapun secara spesifik tujuan penelitian yang akan dijawab pada penelitian ini yaitu: (1). Untuk mengidentifikasi karakteristik kebutuhan pelanggan apa saja yang di anggap penting oleh Modern Laundry, (2). Untuk mengidentifikasi karakteristik kebutuhan pelanggan Modern Laundry ke dalam karakteristik teknis melalui penggunaan House of Quality (HoQ), (3). Untuk mengidentifikasi posisi Modern Laundry dilihat dari karakteristik kebutuhan pelanggan dan karakteristik teknis yang dimiliki oleh Modern Laundry terhadap pesaing, (4). Untuk mengidentifikasi karakteristik kualitas pelayanan yang perlu ditingkatkan oleh Modern Laundry.

\section{METODE DAN DATA}

Penelitian ini merupakan penelitian kualitatif dengan menggunakan analisis deskriptif. Penelitian ini dilakukan pada Modern Laundry di kota Cirebon. Teknis pengumpulan data yang digunakan dalam penelitian ini adalah dengan menggunakan kuesioner dan wawancara. Pada penelitian ini jumlah responden adalah 30 narasumber yang merupakan pelanggan atau nonpelanggan yang pernah merasakan jasa Modern Laundry dan jasa pesaingnya Laundry Kompetitor (Max Coin Laundry). Hasil dari observasi dan wawancara yang dimaksudkan dilakukan dengan mengumpulkan, menyajikan serta menganalisis data sehingga dapat memberikan suatu gambaran yang cukup jelas mengenai objek yang diteliti yang pada akhirnya akan diperoleh suatu kesimpulan (Sekaran, 2010). Uji Validitas dilakukan untuk memastikan instrument pengukuran valid dan uji reliabilitas digunakan untuk menentukan reliabelnya hasil observasi tersebut.

Modern Laundry adalah sebuah badan usaha yang menawarkan jasa dalam hal pencucian pakaian kiloan yang tergolong kedalam UMKM (Usaha Mikro Kecil dan Menengah). Modern Laundry beralamat di jalan Petratean no.72 Kelurahan dan Kecamatan Pekalipan, Kota Cirebon. Letak dari Modern Laundry tergolong strategis karena letaknya berada di tengah Kota Cirebon. Selain terletak di tengah Kota Cirebon, kawasan Modern Laundry pun tergolong ke dalam kawasan yang ramai, dimana di sekelilingnya terdapat banyak ruko yang selalu ramai tiap harinya. Dilihat dari usianya, Modern Laundry tergolong kedalam usia yang matang, karena Modern Laundry sudah berdiri sejak tahun 1976 tepatnya pada bulan Maret.

Teknis analisa data dilakukan dengan menggunakan metode Quality Function Development (QFD). Metode ini diawali dengan menyusun House of Quality (HoQ) dengan langkah-langkah sebagai berikut: Langkah-langkah dalam membangun House of Quality (Cohen, 2010) adalah sebagai berikut:

1. Perusahaan mengidentifikasi semua kebutuhan dan keinginan konsumen terhadap produk yang ada. Kebutuhan dan keingunan konsumen ini disebut sebagai karakteristik kebutuhan konsumen.

2. Perusahaan mengidentifikasi tingkat kepentingan konsumen untuk setiap karakteristik kebutuhan konsumen yang diperoleh. 
3. Seluruh karakteristik kebutuhan konsumen (what's) yang telah dihimpun ditahap pertama diterjemahkan kedalam karakteristik teknis (how's).

4. Setelah informasi mengenai karakteristik kebutuhan konsumen dan karakteristik teknis diketahui, maka selanjutbya adalah ditentukan korelasi antara keduanya.

5. Perusahaan kemudian menentukan targetnya terhadap masing-masing karakteristik teknis yang ada, yang akan diusahakan pencapaiannya guna memenuhi keinginan dan kebutuhan konsumen. Nilai-nilai tersebut diletakan di bagian bawah rumah kualitas.

6. Target perushaan yang sudah ditetapkan, dapat ditingkatkan atau diturunkan sesuai dengan kebijakan perusahaan. Berikut ini simbol yang digunakan:

7. Setelah itu perusahaan menentukan matriks korelasi (Correlation Matrix) antar masing-masing karakteristik teknis yang ada. Setiap hubungannya ditulis dengan lambang yang berbeda sesuai dengan dampak perubahan yang dihasilkan (korelasi positif $(+)$, korelasi negatif $(-)$ ), yang digambarkan pada bagian atas (atap) rumah kualitas dan berbentuk segitiga simetris.

8. Selanjutnya perusahaan menentukan tingkat kesulitan organisasi dalam melaksanakan karakteristik teknis beserta target yang ada (skala 1 sampai 5) dan diletakan dibagian bawah hubungan antar karakteristik kebutuhan konsumen dan karakteristik teknis pada rumah kualitas.

9. Perusahaan kemudian membandingkan produk perusahaan dengan produk perusahaan pesaing berdasarkan karakteristik kebutuhan konsumen yang ada. Data ini diletakan pada bagian kanan rumah kualitas.

10. Setelah itu karakteristik teknis perusahaan dibandingkan dengan karakteristik teknis perusahaan pesaing. Informasi diperoleh dari hasil wawancara dengan pihak bersangkutan dalam perusahaan. Informasi yang diperoleh kemudian diletakkan pada bagian bawah rumah kualitas.

11. Dengan menempatkan angka-angka yang berupa angka pada matriks hubungan whats dan hows, maka seluruh penilaian dapat disusun berdasarkan kepentingan relatif dari setiap keinginan konsumen. Pengurutan nilai ini akan menunjukan bagian-bagian mana yang paling penting menurut pendapat konsumen dan bagian-bagian mana yang memerlukan perhatian penuh dari perusahaan. Langkah perhitungannya adalah sebagai berikut:

a. Kalikan setiap nilai masukan yang berhubungan dengan nilai:

9 untuk hubungan yang kuat, 3 untuk hubungan yang sedang, dan 1 untuk hubungan yang lemah.

b. Total setiap kolom memberikan nilai absolute

c. Nilai relatif merupakan persentase (\%) dari nilai absolute

Berikut adalah tabel Definisi Operasional Variabel, yang digunakan dalam penelitian ini, sebagai berikut:

Tabel 2 Definisi Operasional Variabel

\begin{tabular}{|l|l|l|l|l|l|}
\hline Variabel & \multicolumn{1}{|c|}{ Definisi } & \multicolumn{1}{c|}{ Dimensi } & \multicolumn{1}{c|}{ Indikator } & \multicolumn{1}{c|}{$\begin{array}{c}\text { Item } \\
\text { Pertanyaan }\end{array}$} & Skala \\
\hline $\begin{array}{l}\text { Kualitas } \\
\text { Pelayana } \\
\mathrm{n}\end{array}$ & $\begin{array}{l}\text { Kualitas pelayan } \\
\text { adalah setiap } \\
\text { tindakan atau } \\
\text { kegiatan yang dapat } \\
\text { ditawarkan oleh } \\
\text { satu pihak kepada } \\
\text { pihak lain, pada } \\
\text { dasarnya tidak } \\
\text { berwujud dan tidak } \\
\text { mengakibatkan } \\
\text { perpindahan }\end{array}$ & Tangible & $\begin{array}{l}\text { Penampilan } \\
\text { Fisik }\end{array}$ & $\begin{array}{l}\text { Karyawan } \\
\text { Laundry } \\
\text { berseragam } \\
\text { kerja. }\end{array}$ & Ordinal \\
\cline { 3 - 5 } & & Fasilitas Fisik & $\begin{array}{l}\text { Laundry } \\
\text { memiliki gedung } \\
\text { yang terlihat } \\
\text { menarik dari } \\
\text { luar. }\end{array}$ & Ordinal \\
& & & $\begin{array}{l}\text { Pihak Laundry } \\
\text { memiliki } \\
\text { armada yang }\end{array}$ & Ordinal \\
\cline { 3 - 5 }
\end{tabular}


Volume 25 No 1 Tahun 2021 | 82

\begin{tabular}{|c|c|c|c|c|}
\hline \multirow[t]{10}{*}{$\begin{array}{l}\text { kepemilikan } \\
\text { apapun. }\end{array}$} & & & $\begin{array}{l}\text { memadai dalam } \\
\text { take and delivery } \\
\text { pakaian. }\end{array}$ & \\
\hline & \multirow[t]{3}{*}{ Reliability } & $\begin{array}{l}\text { Ketepatan } \\
\text { Waktu }\end{array}$ & $\begin{array}{l}\text { Lama } \\
\text { pengerjaan } \\
\text { sesuai dengan } \\
\text { waktu yang } \\
\text { telah disepakati } \\
\text { sebelumnya. }\end{array}$ & Ordinal \\
\hline & & $\begin{array}{l}\text { Berupaya bebas } \\
\text { dari kesalahan }\end{array}$ & $\begin{array}{l}\text { Pakaian yang } \\
\text { telah di setrika } \\
\text { selalu tampak } \\
\text { rapi. }\end{array}$ & Ordinal \\
\hline & & Keandalan & $\begin{array}{l}\text { Pihak Laundry } \\
\text { akurat dalam } \\
\text { mengidentifikasi } \\
\text { noda pada } \\
\text { pakaian(setiap } \\
\text { noda yang ada } \\
\text { dipakaian akan } \\
\text { hilang). }\end{array}$ & Ordinal \\
\hline & \multirow[t]{3}{*}{ Responsiveness } & Respon & $\begin{array}{l}\text { Karyawan selalu } \\
\text { siap dalam } \\
\text { merespon } \\
\text { permintaan } \\
\text { pelanggan. }\end{array}$ & Ordinal \\
\hline & & Kecepatan & $\begin{array}{l}\text { Pihak Laundry } \\
\text { cepat dalam } \\
\text { menangani } \\
\text { transaksi } \\
\text { pengambilan \& } \\
\text { pengiriman } \\
\text { pakaian. }\end{array}$ & Ordinal \\
\hline & & $\begin{array}{l}\text { Kesediaan } \\
\text { Membantu }\end{array}$ & $\begin{array}{l}\text { Pihak Laundry } \\
\text { menawarkan } \\
\text { bantuan kepada } \\
\text { pelanggan. }\end{array}$ & Ordinal \\
\hline & \multirow[t]{3}{*}{ Assurance } & Keamanan & $\begin{array}{l}\text { Adanya jaminan } \\
\text { ganti rugi } \\
\text { kehilangan dari } \\
\text { pihak Laundry. }\end{array}$ & Ordinal \\
\hline & & $\begin{array}{l}\text { Pengetahuan } \\
\text { Luas }\end{array}$ & $\begin{array}{l}\text { Pihak Laundry } \\
\text { memiliki } \\
\text { karyawan yang } \\
\text { memiliki } \\
\text { pengetahuan } \\
\text { yang luas. }\end{array}$ & Ordinal \\
\hline & & $\begin{array}{l}\text { Kepercayaan } \\
\text { Pelanggan }\end{array}$ & $\begin{array}{l}\text { Pihak Laundry } \\
\text { memiliki } \\
\text { karyawan yang }\end{array}$ & Ordinal \\
\hline
\end{tabular}




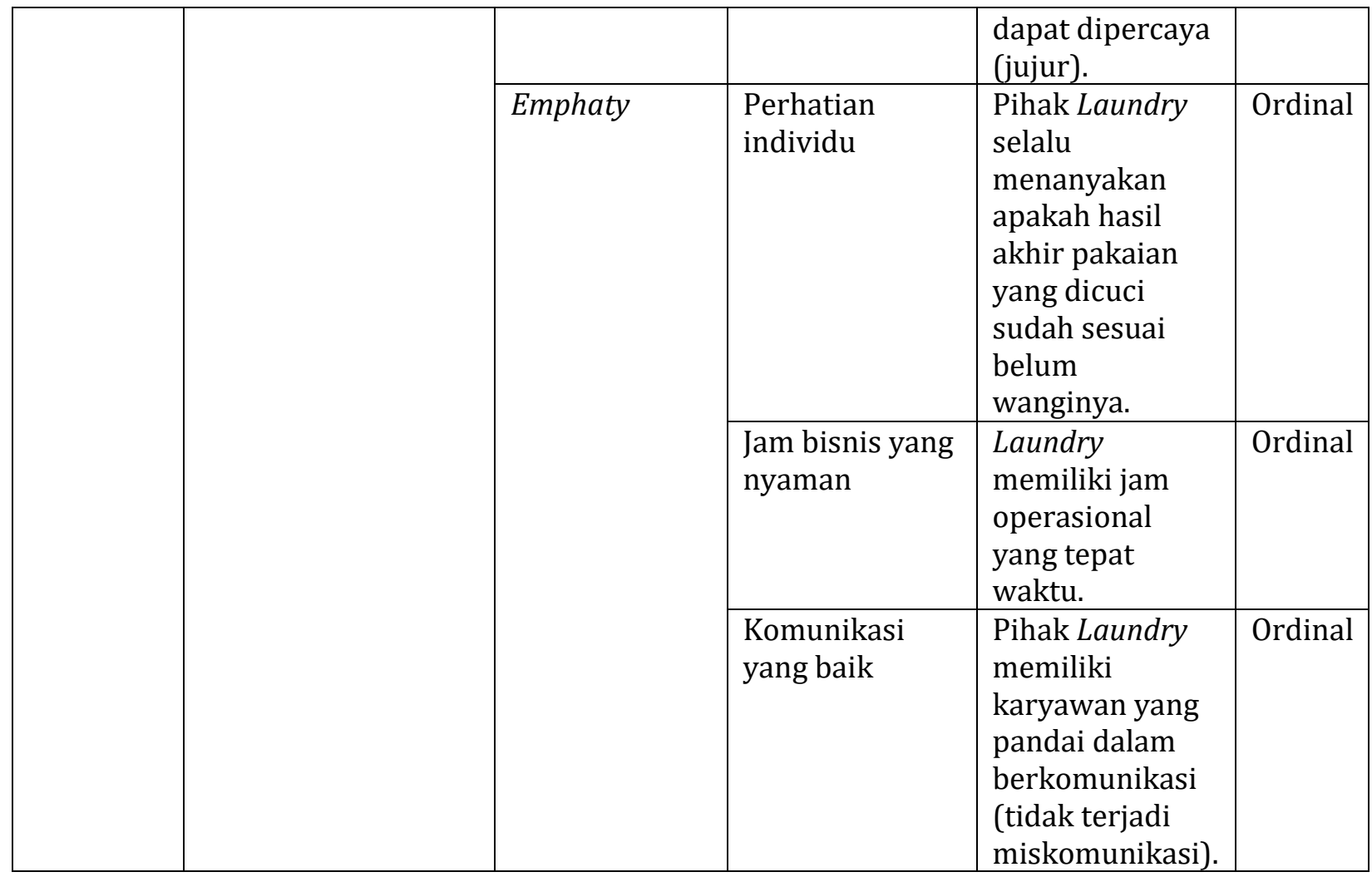

Sumber: Data Diolah (2018)

\section{PEMBAHASAN}

Dalam melakukan analisa kualitas pelayanan di Modern Laundry, dilakukan beberapa tahapan penelitian yaitu pengumpulan data, uji validitas dan reliabilitas, menganalisa tingkat kepentingan dan poin penjualan, menentukan nilai sasaran pelanggan, menentukan faktor skala kenaikan, menentukan poin penjualan, menentukan absolut terbesar persyaratan pelanggan serta menganalisa tingkat kepentingan absolut dan tingkat kepentingan relative. Dalam uji validitas dan reliabilitas seluruh indikator yang digunakan valid dan reliabel sehingga dilanjutkan dengan Langkah selanjutnya.

\section{Tingkat Kepentingan dan Poin Penjualan}

Berikut ini merupakan hasil rangkuman kuesioner tingkat kepentingan yang diberikan kepada 30 pelanggan Modern Laundry.

Tabel 3. Jumlah Jawaban Kuesioner Berdasarkan Tingkat Kepentingan

\begin{tabular}{|l|l|c|c|c|c|c|}
\hline No. & \multicolumn{1}{|c|}{ Atribut } & STP & KP & CP & P & SP \\
\hline 1 & Karyawan Laundry berseragam kerja. & 0 & 0 & 3 & 24 & 3 \\
\hline 2 & $\begin{array}{l}\text { Laundry memiliki gedung yang terlihat } \\
\text { menarik dari luar. }\end{array}$ & 0 & 1 & 7 & 19 & 3 \\
\hline 3 & $\begin{array}{l}\text { Pihak Laundry memiliki armada yang } \\
\text { memadai dalam take and delivery pakaian. }\end{array}$ & 0 & 0 & 2 & 25 & 3 \\
\hline 4 & $\begin{array}{l}\text { Lama pengerjaan sesuai dengan waktu yang } \\
\text { telah disepakati sebelumnya. }\end{array}$ & 0 & 0 & 1 & 25 & 4 \\
\hline 5 & $\begin{array}{l}\text { Pakaian yang telah di setrika selalu tampak } \\
\text { rapi. }\end{array}$ & 0 & 1 & 6 & 8 & 15 \\
\hline
\end{tabular}




\begin{tabular}{|l|l|c|c|c|c|c|}
\hline 6 & $\begin{array}{l}\text { Pihak daumdry akurat } \\
\text { mengidentifikasi noda pada pakaian(setiap } \\
\text { noda yang ada dipakaian akan hilang). }\end{array}$ & 0 & 1 & 5 & 8 & 16 \\
\hline 7 & $\begin{array}{l}\text { Karyawan selalu siap dalam merespon } \\
\text { permintaan pelanggan. }\end{array}$ & 0 & 0 & 4 & 24 & 2 \\
\hline 8 & $\begin{array}{l}\text { Pihak Laundry cepat dalam menangani } \\
\text { transaksi pengambilan \& pengiriman } \\
\text { pakaian. }\end{array}$ & 0 & 0 & 2 & 23 & 5 \\
\hline 9 & $\begin{array}{l}\text { Pihak Laundry menawarkan bantuan kepada } \\
\text { pelanggan. }\end{array}$ & 0 & 0 & 7 & 20 & 3 \\
\hline 10 & $\begin{array}{l}\text { Adanya jaminan ganti rugi kehilangan dari } \\
\text { pihak Laundry. }\end{array}$ & 0 & 1 & 5 & 21 & 3 \\
\hline 11 & $\begin{array}{l}\text { Pihak Laundry memiliki karyawan yang } \\
\text { memiliki pengetahuan yang luas. }\end{array}$ & 0 & 0 & 1 & 26 & 3 \\
\hline 12 & $\begin{array}{l}\text { Pihak Laundry memiliki karyawan yang } \\
\text { dapat dipercaya (jujur). }\end{array}$ & 0 & 0 & 1 & 26 & 3 \\
\hline 13 & $\begin{array}{l}\text { Pihak Laundry selalu menanyakan apakah } \\
\text { hasil akhir pakaian yang dicuci sudah sesuai } \\
\text { belum wanginya. }\end{array}$ & 0 & 1 & 5 & 2 & 22 \\
\hline 14 & $\begin{array}{l}\text { Laundry memiliki jam operasional yang } \\
\text { tepat waktu. }\end{array}$ & 0 & 0 & 3 & 22 & 5 \\
\hline 15 & $\begin{array}{l}\text { Pihak Laundry memiliki karyawan yang } \\
\text { pandai dalam berkomunikasi (tidak terjadi } \\
\text { miskomunikasi). }\end{array}$ & 0 & 0 & 3 & 24 & 3 \\
\hline
\end{tabular}

\section{Sumber: Kuesioner yang sudah diolah 2018}

Keterangan: $\mathrm{STP}=$ Sangat Tidak Penting; $\mathrm{KP}=$ Kurang Penting; $\mathrm{CP}=$ Cukup Penting; $\mathrm{P}=\mathrm{Penting}$; $\mathrm{SP}=$ Sangat Penting. Pada skala ini $\mathrm{STP}$ dinilai dengan angka $1, \mathrm{KP}=2, \mathrm{CP}=3, \mathrm{P}=4$ dan $\mathrm{SP}=5$.

Tabel 3. Menunjukkan jumlah responden jawaban responden berdasarkan tingkat kepentingan pelanggan. Sebagai contoh pada atribut "Karyawan Laundry berseragam kerja", ada 3 responden yang merasa Cukup Penting, 24 responden merasa Penting dan 3 responden merasa Sangat Penting.

Hasil dari tabel 3. Jumlah Jawaban Kuesioner Berdasarkan Tingkat Kepentingan selanjutnya diolah untuk menghasilkan tabel tingkat kepentingan yang didapat dari menentukan nilai yang paling sering muncul atau modus dari setiap atribut. Sebagai contoh pada tabel 4. Digambarkan atribut "karyawan laundry berseragam kerja" dengan nilai tingkat kepentingan 4. Nilai 4 didapat dari tabel 3 yang menunjukkan ada 24 responden (atau paling banyak responden) merasa "Penting" saat merespon atribut tersebut. Kategori "Penting disetarakan dengan nilai 4 sehingga pada tabel 4 . Tingkat kepentingan atribut "karyawan laundry berseragam kerja" diberi skor 4 .

Tabel 4. Tingkat Kepentingan

\begin{tabular}{|c|l|c|}
\hline No. & \multicolumn{1}{|c|}{ Persyaratan Pelanggan (Whats) } & $\begin{array}{c}\text { Tingkat } \\
\text { Kepentingan }\end{array}$ \\
\hline 1 & Karyawan Laundry berseragam kerja. & 4 \\
\hline 2 & Laundry memiliki gedung yang terlihat menarik dari luar. & 4 \\
\hline 3 & $\begin{array}{l}\text { Pihak Laundry memiliki armada yang memadai dalam take and delivery } \\
\text { pakaian. }\end{array}$ & 4 \\
\hline 4 & $\begin{array}{l}\text { Lama pengerjaan sesuai dengan waktu yang telah disepakati } \\
\text { sebelumnya. }\end{array}$ & 4 \\
\hline
\end{tabular}




\begin{tabular}{|c|l|c|}
\hline 5 & Pakaian yang telah di setrika selalu tampak rapi. & 5 \\
\hline 6 & $\begin{array}{l}\text { Pihak Laundry akurat dalam mengidentifikasi noda pada } \\
\text { pakaian(setiap noda yang ada dipakaian akan hilang). }\end{array}$ & 5 \\
\hline 7 & Karyawan selalu siap dalam merespon permintaan pelanggan. & 4 \\
\hline 8 & $\begin{array}{l}\text { Pihak Laundry cepat dalam menangani transaksi pengambilan \& } \\
\text { pengiriman pakaian. }\end{array}$ & 4 \\
\hline 9 & Pihak Laundry menawarkan bantuan kepada pelanggan. & 4 \\
\hline 10 & Adanya jaminan ganti rugi kehilangan dari pihak Laundry. & 4 \\
\hline 11 & $\begin{array}{l}\text { Pihak Laundry memiliki karyawan yang memiliki pengetahuan yang } \\
\text { luas. }\end{array}$ & 4 \\
\hline 12 & Pihak Laundry memiliki karyawan yang dapat dipercaya (jujur). & 4 \\
\hline 13 & $\begin{array}{l}\text { Pihak Laundry selalu menanyakan apakah hasil akhir pakaian yang } \\
\text { dicuci sudah sesuai belum wanginya. }\end{array}$ & 5 \\
\hline 14 & Laundry memiliki jam operasional yang tepat waktu. \\
\hline 15 & $\begin{array}{l}\text { Pihak Laundry memiliki karyawan yang pandai dalam berkomunikasi } \\
\text { (tidak terjadi miskomunikasi). }\end{array}$ & 4 \\
\hline
\end{tabular}

\section{Nilai Sasaran Pelanggan}

Langkah selanjutnya adalah menentukan nilai sasaran pelanggan melalui hasil evaluasi jawaban kuesioner pelanggan Modern Laundry jika dibandingan jasa Laundry kompetitor. Tabel 5. menunjukkan posisi nilai sasaran Modern Laundry adalah 4 untuk atribut karyawan laundry berseragam kerja, sedangkan Laundry "Kompetitor" juga memiliki nilai 4 sehingga berdasarkan wawancara dengan pihak manajemen Modern Laundry ditetapkan nilai sasaran Modern Laundry adalah 4. Hal ini dilakukan juga pada atribut lainnya.

Tabel 5. Nilai Sasaran Pelanggan

\begin{tabular}{|c|l|c|c|c|}
\hline No. & \multicolumn{1}{|c|}{ Atribut } & $\begin{array}{c}\text { Modern } \\
\text { Laundry }\end{array}$ & $\begin{array}{c}\text { Laundry } \\
\text { Kompetitor }\end{array}$ & $\begin{array}{c}\text { Nilai Sasaran } \\
\text { (Modern Laundry) }\end{array}$ \\
\hline 1 & Karyawan Laundry berseragam kerja. & 4 & 4 & 4 \\
\hline 2 & $\begin{array}{l}\text { Laundry memiliki gedung yang terlihat } \\
\text { menarik. }\end{array}$ & 3 & 4 & 5 \\
\hline 3 & $\begin{array}{l}\text { Pihak Laundry memiliki armada yang } \\
\text { memadai dalam take and delivery } \\
\text { pakaian. }\end{array}$ & 4 & 5 & 4 \\
\hline 4 & $\begin{array}{l}\text { Lama pengerjaan sesuai dengan waktu } \\
\text { yang telah disepakati sebelumnya. }\end{array}$ & 4 & 4 & 5 \\
\hline 5 & $\begin{array}{l}\text { Pakaian yang telah di setrika selalu } \\
\text { tampak rapi. }\end{array}$ & 4 & 5 & 5 \\
\hline 6 & $\begin{array}{l}\text { Pihak Laundry akurat dalam } \\
\text { mengidentifikasi noda pada pakaian } \\
\text { (setiap noda yang ada dipakaian akan } \\
\text { hilang). }\end{array}$ & 4 & 5 & 4 \\
\hline 7 & $\begin{array}{l}\text { Karyawan selalu siap dalam merespon } \\
\text { permintaan pelanggan. }\end{array}$ & 3 & 4 & 4 \\
\hline 8 & $\begin{array}{l}\text { Pihak Laundry cepat dalam menangani } \\
\text { transaksi pengambilan \& pengiriman } \\
\text { pakaian. }\end{array}$ & 4 & 4 & \\
\hline
\end{tabular}




\begin{tabular}{|c|c|c|c|c|}
\hline 9 & $\begin{array}{l}\text { Pihak Laundry menawarkan bantuan } \\
\text { kepada pelanggan. }\end{array}$ & 4 & 4 & 4 \\
\hline 10 & $\begin{array}{l}\text { Adanya jaminan ganti rugi kehilangan } \\
\text { dari pihak Laundry. }\end{array}$ & 4 & 4 & 4 \\
\hline 11 & $\begin{array}{l}\text { Pihak Laundry memiliki karyawan yang } \\
\text { memiliki pengetahuan yang luas. }\end{array}$ & 4 & 3 & 4 \\
\hline 12 & $\begin{array}{l}\text { Pihak Laundry memiliki karyawan yang } \\
\text { dapat dipercaya (jujur). }\end{array}$ & 5 & 4 & 5 \\
\hline 13 & $\begin{array}{l}\text { Laundry selalu menanyakan apakah } \\
\text { hasil akhir pakaian yang dicuci sudah } \\
\text { sesuai belum wanginya. }\end{array}$ & 4 & 5 & 5 \\
\hline 14 & $\begin{array}{l}\text { Laundry memiliki jam operasional yang } \\
\text { tepat waktu. }\end{array}$ & 5 & 4 & 5 \\
\hline 15 & $\begin{array}{l}\text { Pihak Laundry memiliki karyawan yang } \\
\text { pandai dalam berkomunikasi (tidak } \\
\text { terjadi miskomunikasi). }\end{array}$ & 4 & 4 & 4 \\
\hline
\end{tabular}

Sumber: Kuesioner yang sudah diolah 2018

\section{Faktor Skala Kenaikan (Scale-Up Factor)}

Faktor skala kenaikan menunjukkan suatu ukuran upaya pihak Modern Laundry dalam usaha perbaikan kualitas pelayanannya pada setiap karakteristik kebutuhan dan keinginan pelanggan. Faktor Skala Kenaikan dinilai berdasarkan Nilai Sasaran yang ditetapkan dihitung dengan membagi nilai sasaran Modern Laundry dengan kondisi real yang terjadi di Modern Laundry. Sebagai contoh pada tabel 5. Faktor Skala Kenaikan pada atribut Karyawan Laundry berseragam kerja diperoleh dari kolom A (Nilai Sasaran Modern Laundry) dibagi nilai pada kolom B (Nilai Modern Laundry) yaitu kondisi atribut pada Modern Laundry saat dilakukan wawancara. Perhitungan Faktor Skala Kenaikan dilakukan untuk setiap atribut yang ada seperti tampak pada tabel 6.

Tabel 6. Faktor Skala Kenaikan

\begin{tabular}{|c|l|c|c|c|}
\hline No. & \multicolumn{1}{|c|}{ Atribut } & $\begin{array}{c}\text { Nilai Sasaran } \\
\text { (Modern } \\
\text { Laundry) } \\
\text { (A) }\end{array}$ & $\begin{array}{c}\text { Laundry } \\
\text { (B) }\end{array}$ & $\begin{array}{c}\text { Faktor Skala } \\
\text { Kenaikan } \\
\text { (A/B) }\end{array}$ \\
\hline 1 & Karyawan Laundry berseragam kerja. & 4 & 4 & 1 \\
\hline 2 & $\begin{array}{l}\text { Laundry memiliki gedung yang terlihat } \\
\text { menarik dari luar. }\end{array}$ & 4 & 3 & 1.33 \\
\hline 3 & $\begin{array}{l}\text { Pihak Laundry memiliki armada yang } \\
\text { memadai dalam take and delivery pakaian. }\end{array}$ & 5 & 4 & 1.25 \\
\hline 4 & $\begin{array}{l}\text { Lama pengerjaan sesuai dengan waktu } \\
\text { yang telah disepakati sebelumnya. }\end{array}$ & 4 & 4 & 1.25 \\
\hline 5 & $\begin{array}{l}\text { Pakaian yang telah di setrika selalu tampak } \\
\text { rapi. }\end{array}$ & 5 & 4 & 1.25 \\
\hline 6 & $\begin{array}{l}\text { Pihak Laundry akurat dalam } \\
\text { mengidentifikasi noda pada pakaian(setiap } \\
\text { noda yang ada dipakaian akan hilang). }\end{array}$ & 5 & 3 & 1.33 \\
\hline 7 & $\begin{array}{l}\text { Karyawan selalu siap dalam merespon } \\
\text { permintaan pelanggan. }\end{array}$ & 4 & 4 & 1 \\
\hline 8 & $\begin{array}{l}\text { Pihak Laundry cepat dalam menangani } \\
\text { transaksi pengambilan \& pengiriman } \\
\text { pakaian. }\end{array}$ & 4 & & 4 \\
\hline
\end{tabular}




\begin{tabular}{|c|c|c|c|c|}
\hline 9 & $\begin{array}{l}\text { Pihak Laundry menawarkan bantuan } \\
\text { kepada pelanggan. }\end{array}$ & 4 & 4 & 1 \\
\hline 10 & $\begin{array}{l}\text { Adanya jaminan ganti rugi kehilangan dari } \\
\text { pihak Laundry. }\end{array}$ & 4 & 4 & 1 \\
\hline 11 & $\begin{array}{l}\text { Pihak Laundry memiliki karyawan yang } \\
\text { memiliki pengetahuan yang luas. }\end{array}$ & 4 & 3 & 1.33 \\
\hline 12 & $\begin{array}{l}\text { Pihak Laundry memiliki karyawan yang } \\
\text { dapat dipercaya (jujur). }\end{array}$ & 5 & 4 & 1.25 \\
\hline 13 & $\begin{array}{l}\text { Pihak Laundry selalu menanyakan apakah } \\
\text { hasil akhir pakaian yang dicuci sudah } \\
\text { sesuai belum wanginya. }\end{array}$ & 5 & 5 & 1 \\
\hline 14 & $\begin{array}{l}\text { Laundry memiliki jam operasional yang } \\
\text { tepat waktu. }\end{array}$ & 5 & 4 & 1.25 \\
\hline 15 & $\begin{array}{l}\text { Pihak Laundry memiliki karyawan yang } \\
\text { pandai dalam berkomunikasi. }\end{array}$ & 4 & 4 & 1 \\
\hline
\end{tabular}

\section{Poin Penjualan}

\section{Sumber: Kuesioner yang sudah diolah (2018)}

Poin penjualan memberikan informasi mengenai persyaratan pelanggan mana saja yang dianggap akan membantu penjualan produk maupun jasa. Dalam penelitian ini, poin penjualan berupa nilai yang sudah ditentukan yaitu 1.0 untuk persyaratan pelanggan yang dianggap tidak membantu dalam penjualan, 1.2 untuk persyaratan pelanggan yang cukup membatu dalam penjualan, dan 1.5 untuk persyaratan pelanggan yang membantu dalam penjualan (Cohen, 2010). Berikut Tabel 7 yang menunjukkan nilai poin penjualan untuk setiap atribut dalam penelitian ini yang akan digunakan dalam menghitung Bobot Absolut pada langkah selanjutnya.

Tabel 7. Poin Penjualan

\begin{tabular}{|c|c|c|}
\hline No. & Persyaratan Pelanggan (Whats) & $\begin{array}{c}\text { Poin } \\
\text { Penjualan }\end{array}$ \\
\hline 1 & Karyawan Laundry berseragam kerja. & 1.2 \\
\hline 2 & $\begin{array}{l}\text { Laundry memiliki gedung yang terlihat menarik } \\
\text { dari luar. }\end{array}$ & 1.2 \\
\hline 3 & $\begin{array}{l}\text { Pihak Laundry memiliki armada yang memadai } \\
\text { dalam take and delivery pakaian. }\end{array}$ & 1.5 \\
\hline 4 & $\begin{array}{l}\text { Lama pengerjaan sesuai dengan waktu yang telah } \\
\text { disepakati sebelumnya. }\end{array}$ & 1.5 \\
\hline 5 & Pakaian yang telah di setrika selalu tampak rapi. & 1.5 \\
\hline 6 & $\begin{array}{l}\text { Pihak Laundry akurat dalam mengidentifikasi noda } \\
\text { pada pakaian(setiap noda yang ada dipakaian akan } \\
\text { hilang). }\end{array}$ & 1.2 \\
\hline 7 & $\begin{array}{l}\text { Karyawan selalu siap dalam merespon permintaan } \\
\text { pelanggan. }\end{array}$ & 1.2 \\
\hline 8 & $\begin{array}{l}\text { Pihak Laundry cepat dalam menangani transaksi } \\
\text { pengambilan \& pengiriman pakaian. }\end{array}$ & 1.5 \\
\hline 9 & $\begin{array}{l}\text { Pihak Laundry menawarkan bantuan kepada } \\
\text { pelanggan. }\end{array}$ & 1.2 \\
\hline 10 & $\begin{array}{l}\text { Adanya jaminan ganti rugi kehilangan dari pihak } \\
\text { Laundry. }\end{array}$ & 1.5 \\
\hline 11 & $\begin{array}{l}\text { Pihak Laundry memiliki karyawan yang memiliki } \\
\text { pengetahuan yang luas. }\end{array}$ & 1.5 \\
\hline
\end{tabular}


Volume 25 No 1 Tahun 2021 | 88

\begin{tabular}{|c|l|c|}
\hline 12 & $\begin{array}{l}\text { Pihak Laundry memiliki karyawan yang dapat } \\
\text { dipercaya (jujur). }\end{array}$ & 1.5 \\
\hline 13 & $\begin{array}{l}\text { Pihak Laundry selalu menanyakan apakah hasil } \\
\text { akhir pakaian yang dicuci sudah sesuai belum } \\
\text { wanginya. }\end{array}$ & 1.5 \\
\hline 14 & $\begin{array}{l}\text { Laundry memiliki jam operasional yang tepat } \\
\text { waktu. }\end{array}$ & 1.5 \\
\hline 15 & $\begin{array}{l}\text { Pihak Laundry memiliki karyawan yang pandai } \\
\text { dalam berkomunikasi (tidak terjadi } \\
\text { miskomunikasi). }\end{array}$ & \\
\hline
\end{tabular}

Sumber: Kuesioner yang sudah diolah 2018

\section{Bobot Absolute Persyaratan Pelanggan}

Langkah selanjutnya adalah menentukan bobot absolut dengan cara memberikan bobot pada bagian ini adalah dengan mengalikan seluruh bobot pada tingkat kepentingan, skala kenaikan, dan poin penjualan pada masing-masing karakteristik persyaratan pelanggan atau atribut. Tabel 8 . Menggambarkan perhitungan bobot absolut persyaratan pelanggan dari setiap atribut. Setelah menjumlahkan semua bobot absolut, kemudian dihitung persentase (\%) ranking untuk setiap persyaratan pelanggan.

Tabel 8. Tabel Bobot Absolut Persyaratan Pelanggan

\begin{tabular}{|c|l|c|c|c|c|}
\hline No & \multicolumn{1}{|c|}{ Atribut } & $\begin{array}{c}\text { Tingkat } \\
\text { Kepentingan } \\
\text { (A) }\end{array}$ & $\begin{array}{c}\text { Skala } \\
\text { Kenaikan } \\
\text { (B) }\end{array}$ & $\begin{array}{c}\text { Poin } \\
\text { Penjualan } \\
\text { (C) }\end{array}$ & $\begin{array}{c}\text { Bobot } \\
\text { Absolut } \\
\text { (AxBXC) }\end{array}$ \\
\hline 1 & $\begin{array}{l}\text { Karyawan Laundry berseragam } \\
\text { kerja. }\end{array}$ & 4 & 1 & 1.2 & 4.8 \\
\hline 2 & $\begin{array}{l}\text { Laundry memiliki gedung yang } \\
\text { terlihat menarik dari luar. }\end{array}$ & 4 & 1.33 & 1.2 & 6.384 \\
\hline 3 & $\begin{array}{l}\text { Pihak Laundry memiliki armada } \\
\text { yang memadai dalam take and } \\
\text { delivery pakaian. }\end{array}$ & 4 & 1.25 & 1.5 & 7.5 \\
\hline 4 & $\begin{array}{l}\text { Lama pengerjaan sesuai dengan } \\
\text { waktu yang telah disepakati } \\
\text { sebelumnya. }\end{array}$ & 4 & 1 & 1.5 & 6 \\
\hline 5 & $\begin{array}{l}\text { Pakaian yang telah di setrika selalu } \\
\text { tampak rapi. }\end{array}$ & 5 & 1.25 & 1.5 & 9.375 \\
\hline 6 & $\begin{array}{l}\text { Pihak Laundry akurat dalam } \\
\text { mengidentifikasi noda pada } \\
\text { pakaian(setiap noda yang ada } \\
\text { dipakaian akan hilang). }\end{array}$ & 5 & 1.25 & 1.2 & 7.5 \\
\hline 7 & $\begin{array}{l}\text { Karyawan selalu siap dalam } \\
\text { merespon permintaan pelanggan. }\end{array}$ & 4 & 1.33 & 1.2 & 6.384 \\
\hline 8 & $\begin{array}{l}\text { Pihak Laundry cepat dalam } \\
\text { menangani transaksi pengambilan \& } \\
\text { pengiriman pakaian. }\end{array}$ & 4 & 1 & 1.5 & 6 \\
\hline 9 & $\begin{array}{l}\text { Pihak Laundrymenawarkan bantuan } \\
\text { kepada pelanggan. jaminan ganti rugi }\end{array}$ & 4 & 1.2 & 4.8 \\
\hline 10 & $\begin{array}{l}\text { Adanya jamangang } \\
\text { kehilangan dari pihak Laundry. }\end{array}$ & 4 & 1.5 & 6 \\
\hline
\end{tabular}




\begin{tabular}{|c|l|c|c|c|c|}
\hline 11 & $\begin{array}{l}\text { Pihak Laundry memiliki karyawan } \\
\text { yang memiliki pengetahuan yang } \\
\text { luas. }\end{array}$ & 4 & 1.33 & 1.5 & 7.98 \\
\hline 12 & $\begin{array}{l}\text { Pihak Laundry memiliki karyawan } \\
\text { yang dapat dipercaya (jujur). }\end{array}$ & 4 & 1.25 & 1.5 & 7.5 \\
\hline 13 & $\begin{array}{l}\text { Pihak Laundry selalu menanyakan } \\
\text { apakah hasil akhir pakaian yang } \\
\text { dicuci sudah sesuai belum wanginya. }\end{array}$ & 5 & 1 & 1.5 & 7.5 \\
\hline 14 & $\begin{array}{l}\text { Laundry memiliki jam operasional } \\
\text { yang tepat waktu. }\end{array}$ & 4 & 1.25 & 1.5 & 7.5 \\
\hline 15 & $\begin{array}{l}\text { Pihak Laundry memiliki karyawan } \\
\text { yang pandai dalam berkomunikasi } \\
\text { (tidak terjadi miskomunikasi). }\end{array}$ & 4 & 1 & 1.5 & 6 \\
\hline
\end{tabular}

Sumber: Kuesioner yang sudah diolah 2018

Berdasarkan Tabel 7, maka dapat disimpulkan bahwa terdapat beberapa urutan persyaratan pelanggan. Persyaratan pelangggan dapat diurutkan dari nilai absolut terbesar hingga persyaratan pelanggan yang memiliki nilai absolut terkecil. Adapun hasil urutan persyaratan pelanggan berdasarkan tabel 7 adalah sebagai berikut:

1. Persyaratan pelanggan yang memiliki bobot absolut tertinggi pertama atau prioritas pertama sebesar 9.375 yaitu atribut kelima yaitu "Pakaian yang telah di setrika selalu tampak rapi".

2. Persyaratan pelanggan yang memiliki bobot absolut tertinggi kedua atau prioritas kedua sebesar 7.98 yaitu atribut "Pihak Laundry memiliki karyawan yang memiliki pengetahuan yang luas"

3. Persyaratan pelanggan yang memiliki bobot absolut tertinggi ketiga atau prioritas ketiga sebesar 7.5 yaitu atribut "Pihak Laundry memiliki armada yang memadai dalam take and delivery pakaian" serta atribut "Pihak Laundry akurat dalam mengidentifikasi noda pada pakaian(setiap noda yang ada dipakaian akan hilang)" begitu pula dengan atribut "Pihak Laundry memiliki karyawan yang dapat dipercaya (jujur)" dan atribut "Pihak Laundry selalu menanyakan apakah hasil akhir pakaian yang dicuci sudah sesuai belum wanginya" serta atribut "Laundry memiliki jam operasional yang tepat waktu"

4. Persyaratan pelanggan yang memiliki bobot absolut tertinggi keempat atau prioritas keempat sebesar 6.384 yaitu atribut "Laundry memiliki gedung yang terlihat menarik dari luar. Dan atribut "Karyawan selalu siap dalam merespon permintaan pelanggan"

5. Persyaratan pelanggan yang memiliki bobot absolut sebagai prioritas kelima sebesar 6, yaitu atribut "Lama pengerjaan sesuai dengan waktu yang telah disepakati sebelumnya"; atribut "Pihak Laundry cepat dalam menangani transaksi pengambilan \& pengiriman pakaian"; atribut "Adanya jaminan ganti rugi kehilangan dari pihak Laundry" dan atribut "Pihak Laundry memiliki karyawan yang pandai dalam berkomunikasi (tidak terjadi miskomunikasi)".

6. Persyaratan pelanggan yang memiliki bobot absolut sebagai prioritas terakhir sebesar 4.8, yaitu atribut "Karyawan Laundry berseragam kerja" dan atribut "Pihak Laundry menawarkan bantuan kepada pelanggan".

\section{Tingkat Kepentingan Absolut Dan Tingkat Kepentingan Relatif}

Pada tahap ini akan dilakukan perhitungan untuk memperoleh nilai tingkat kepentingan absolut dan nilai tingkat kepentingan relatif untuk setiap karakteristik teknis perusahaan. Penetapan tingkat kepentingan absolut diperoleh dari perkalian antara tingkat kepentingan kebutuhan pelanggan dengan nilai hubungan antara kebutuhan pelanggan dengan karakteristik teknis perusahaan. Tahap ini merupakan tahap akhir dari proses pembentukan House of Quality. Tingkat kepentingan absolut yang sudah dihitung kemudian diubah kedalam bentuk persen sehingga menjadi tingkat kepentingan relatif. Untuk memperoleh kepentingan relatif maka: 


\section{Nilai tingkat kepentingan absolut suatu karakteristik teknis Total nilai tingkat kepentingan absolut}

Hasil perhitungan tersebut akan di urutkan dari nilai terbesar hingga nilai terkecil. Semakin besar nilainya maka akan menjadi prioritas utama yang akan di terapkan oleh perusahaan. Adapun hasil perhitingan bobot absolut dan persentase persyaratan teknis dapat dilihat pada tabel 8 berikut ini:

Tabel 8. Perhitungan Bobot Absolut Perhitungan Teknis

\begin{tabular}{|c|c|c|c|c|c|c|c|}
\hline $\begin{array}{l}\mathbf{N} \\
\mathbf{o}\end{array}$ & $\begin{array}{c}\text { Persyaratan } \\
\text { Teknis }\end{array}$ & $\begin{array}{c}\text { Persyaratan } \\
\text { Pelanggan }\end{array}$ & $\begin{array}{c}\text { Nilai } \\
\text { Hubungan }\end{array}$ & $\begin{array}{c}\text { Tingkat } \\
\text { Kepentingan }\end{array}$ & \multicolumn{2}{|c|}{$\begin{array}{l}\text { Kepentingan } \\
\text { Absolut / total }\end{array}$} & $\begin{array}{l}\text { Kepentingan } \\
\text { Relatif }\end{array}$ \\
\hline 1 & $\begin{array}{l}\text { Menetapkan } \\
\text { standar } \\
\text { seragam kerja } \\
\text { karyawan. }\end{array}$ & $\begin{array}{l}\text {-Karyawan } \\
\text { Laundry } \\
\text { berseragam } \\
\text { kerja. }\end{array}$ & 9 & 4 & 36 & 36 & $7.64 \%$ \\
\hline 2 & $\begin{array}{l}\text { Memasangkan } \\
\text { spanduk } \\
\text { promosi pada } \\
\text { toko bagian } \\
\text { luar Laundry. }\end{array}$ & $\begin{array}{l}\text {-Laundry } \\
\text { memiliki gedung } \\
\text { yang terlihat } \\
\text { menarik dari } \\
\text { luar. }\end{array}$ & 3 & 4 & 12 & 12 & $2.55 \%$ \\
\hline 3 & $\begin{array}{l}\text { Menambahkan } \\
\text { armada } \\
\text { layanan take } \\
\text { and delivery. }\end{array}$ & $\begin{array}{l}\text {-Pihak Laundry } \\
\text { memiliki } \\
\text { armada yang } \\
\text { memadai dalam } \\
\text { take and delivery } \\
\text { pakaian }\end{array}$ & 9 & 4 & 36 & 36 & $7.64 \%$ \\
\hline 4 & $\begin{array}{l}\text { Mengadakan } \\
\text { pelatihan } \\
\text { etika. }\end{array}$ & $\begin{array}{l}\text {-Lama } \\
\text { pengerjaan } \\
\text { sesuai dengan } \\
\text { waktu yang } \\
\text { telah disepakati } \\
\text {-Pihak Laundry } \\
\text { memiliki } \\
\text { karyawan yang } \\
\text { dapat dipercaya } \\
\text { (jujur) }\end{array}$ & 3 & 4 & 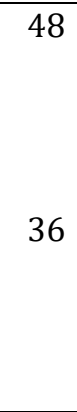 & 84 & $17.83 \%$ \\
\hline 5 & $\begin{array}{l}\text { Mengadakan } \\
\text { Laundry } \\
\text { operational } \\
\text { training } \\
\text { kepada } \\
\text { karyawan } \\
\text { baru. }\end{array}$ & $\begin{array}{l}\text {-Pakaian yang } \\
\text { telah disetrika } \\
\text { selalu tampak } \\
\text { rapi. } \\
\text {-Pihak Laundry } \\
\text { akurat dalam } \\
\text { mengidentifikasi } \\
\text { noda pada } \\
\text { pakaian. } \\
\text {-Pihak Laundry } \\
\text { memiliki } \\
\text { karyawan yang } \\
\text { memiliki } \\
\text { pengetahuan } \\
\text { yang luas. }\end{array}$ & 9 & 5 & 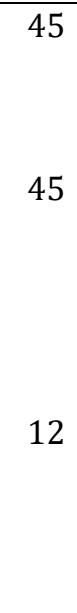 & 102 & $21.66 \%$ \\
\hline
\end{tabular}




\begin{tabular}{|c|c|c|c|c|c|c|c|}
\hline 6 & $\begin{array}{l}\text { Menambahkan } \\
\text { layanan } \\
\text { berbasis media } \\
\text { sosial. } \\
\text { (WhatsApp, } \\
\text { Line). }\end{array}$ & $\begin{array}{l}\text {-Karyawan } \\
\text { selalu siap } \\
\text { dalam merespon } \\
\text { permintaan } \\
\text { pelanggan. }\end{array}$ & 9 & 4 & 36 & 36 & $7.64 \%$ \\
\hline 7 & $\begin{array}{l}\text { Menetapkan } \\
\text { jadwal } \\
\text { pengambilan } \\
\text { dan } \\
\text { pengiriman. }\end{array}$ & $\begin{array}{l}\text {-Pihak Laundry } \\
\text { cepat dalam } \\
\text { menangani } \\
\text { transaksi } \\
\text { pengambilan } \\
\text { dan pengiriman } \\
\text { pakaian. }\end{array}$ & 9 & 4 & 36 & 36 & $7.64 \%$ \\
\hline 8 & $\begin{array}{l}\text { Meningkatkan } \\
\text { kepedulian } \\
\text { kepada } \\
\text { pelanggan. }\end{array}$ & $\begin{array}{l}\text {-Pihak Laundry } \\
\text { menawarkan } \\
\text { bantuan kepada } \\
\text { pelanggan }\end{array}$ & 3 & 4 & 12 & 12 & $2.55 \%$ \\
\hline 9 & $\begin{array}{l}\text { Memberikan } \\
\text { layanan gratis } \\
\text { sebanyak } 2 \\
\text { kali transaksi } \\
\text { jika terjadi } \\
\text { kehilangan. }\end{array}$ & $\begin{array}{lr}\text {-Adanya } & \\
\text { jaminan ganti } \\
\text { rugi kehilangan } \\
\text { dari r pihak } \\
\text { Laundry. }\end{array}$ & 9 & 4 & 36 & 36 & $7.64 \%$ \\
\hline 10 & $\begin{array}{l}\text { Mengevaluasi } \\
\text { keinginan } \\
\text { pelanggan. }\end{array}$ & 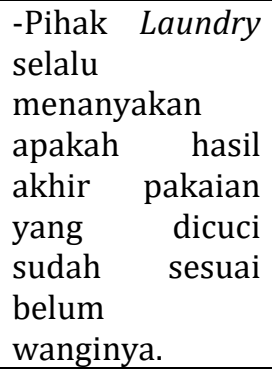 & 9 & 5 & 45 & 45 & $9.55 \%$ \\
\hline 11 & $\begin{array}{l}\text { Buka dan } \\
\text { tutup sesuai } \\
\text { dengan jadwal } \\
\text { yang telah } \\
\text { ditetapkan }\end{array}$ & $\begin{array}{l}\text {-Laundry } \\
\text { memiliki jam } \\
\text { operasional } \\
\text { yang tepat } \\
\text { waktu. }\end{array}$ & 9 & 4 & 36 & 36 & $7.64 \%$ \\
\hline 12 & $\begin{array}{l}\text { Mengadakan } \\
\text { training } \\
\text { communication } \\
\text { skill }\end{array}$ & $\begin{array}{l}\text {-Pihak Laundry } \\
\text { memiliki } \\
\text { karyawan yang } \\
\text { pandai dalam } \\
\text { berkomunikasi. }\end{array}$ & 9 & 4 & 36 & 36 & $7.64 \%$ \\
\hline \multicolumn{3}{|c|}{ TOTAL } & & & & 471 & $100 \%$ \\
\hline
\end{tabular}

Tingkat kepentingan absolut dan tingkat kepentingan relatif berguna untuk mengetahui tingkat karakteristik teknis yang perlu diutamakan. Semakin tinggi nilai absolut maka semakin penting karakteristik teknis perusahaan tersebut dalam memenuhi kebutuhan pelanggan. Sehingga berdasarkan hasil perhitungan dari tabel 8 maka disusun sebuah urutan prioritas karakteristik teknis Modern Laundry seperti dapat dilihat pada tabel 9 dibawah ini:

Tabel 9. Urutan Tingkat Kepentingan Absolut dan Tingkat Kepentingan Relatif

\begin{tabular}{|l|l|c|c|}
\hline No. & \multicolumn{1}{|c|}{ Karakteristik Teknis } & $\begin{array}{c}\text { Kepentingan } \\
\text { Absolut }\end{array}$ & $\begin{array}{c}\text { Kepentingan } \\
\text { Relatif }\end{array}$ \\
\hline 1 & $\begin{array}{l}\text { Mengadakan Laundry operational training } \\
\text { kepada karyawan baru. }\end{array}$ & 102 & $21.66 \%$ \\
\hline
\end{tabular}




\begin{tabular}{|l|l|c|c|}
\hline 2 & Mengadakan pelatihan etika. & 84 & $17,83 \%$ \\
\hline 3 & Mengevaluasi keinginan pelanggan. & 45 & $9.55 \%$ \\
\hline 4 & Menetapkan standar seragam kerja karyawan. & 36 & $7.64 \%$ \\
\hline 5 & $\begin{array}{l}\text { Menambahkan armada layanan take and } \\
\text { delivery. }\end{array}$ & 36 & $7.64 \%$ \\
\hline 6 & $\begin{array}{l}\text { Menambahkan layanan berbasis media sosial. } \\
\text { (WhatsApp, Line). }\end{array}$ & 36 & $7.64 \%$ \\
\hline 7 & $\begin{array}{l}\text { Menetapkan jadwal pengambilan dan } \\
\text { pengiriman. }\end{array}$ & 36 & $7.64 \%$ \\
\hline 8 & $\begin{array}{l}\text { Memberikan layanan gratis sebanyak 2 kali } \\
\text { transaksi jika terjadi kehilangan. }\end{array}$ & 36 & $7.64 \%$ \\
\hline 9 & $\begin{array}{l}\text { Buka dan tutup sesuai dengan jadwal yang } \\
\text { telah ditetapkan. }\end{array}$ & 36 & $7.64 \%$ \\
\hline 10 & Mengadakan training communication skill & 12 & $2.55 \%$ \\
\hline 11 & $\begin{array}{l}\text { Memasangkan spanduk promosi pada toko } \\
\text { bagian luar Laundry. }\end{array}$ & 12 & $2.55 \%$ \\
\hline 12 & Meningkatkan kepedulian kepada pelanggan. & 2018 \\
\hline
\end{tabular}

\section{Sumber: Kuesioner yang sudah diolah 2018}

\section{SIMPULAN}

Berdasarkan data yang telah didapat dan diolah selama penelitian dapat ditarik kesimpulan sebagai berikut:

1. Karakteristik kebutuhan dan keinginan pelanggan yang dianggap penting oleh pelanggan Modern Laundry dibagi menjadi dua kategori yaitu sangat penting dan penting.

a) Berdasarkan hasil analisis maka dapat diketahui karakteristik kebutuhan dan keinginan pelanggan yang dinilai sangat penting dalam meningkatkan kualitas pelayanan Modern Laundry adalah pakaian yang telah disetrika selalu tampak rapi, pihak Laundry akurat dalam mengidentifikasi noda pakaian (setiap noda yang ada di pakaian akan hilang), dan pihak Laundry selalu menanyakan apakah hasil akhir pakaian yang dicuci sudah sesuai belum wanginya.

b) Sedangkan untuk karakteristik kebutuhan dan keinginan pelanggan yang dinilai penting dalam meningkatkan kualitas pelayanan Modern Laundry adalah karyawan Laundry berseragam kerja, Laundry memiliki gedung yang terlihat menarik dari luar, pihak Laundry memiliki armada yang memadai dalam take and delivery pakaian, lama pengerjaan sesuai dengan waktu yang telah disepakati sebelumnya, karyawan selalu siap dalam merespon permintaan pelanggan, pihak Laundry cepat dalam menangani transaksi pengambilan dan pengiriman pakaian, pihak Laundry menawarkan bantuan kepada pelanggan, adanya jaminan ganti rugi kehilangan dari pihak Laundry, pihak Laundry memiliki karyawan yang memiliki pengetahuan yang luas pihak Laundry memiliki karyawan yang dapat dipercaya (jujur), Laundry memiliki jam operasional yang tepat waktu, dan pihak Laundry memiliki karyawan yang pandai dalam berkomunikasi (tidak terjadi miskomunikasi).

2. Untuk menerjemahkan karakteristik kebutuhan pelanggan Modern Laundry kedalam karakteristik teknis dilakukan dengan melakukan wawancara kepada pemilik laundry. Adapun karakteristik teknis yang diperoleh adalah sebagai berikut:

a) Menetapkan standar seragam kerja karyawan.

b) Memasangkan spanduk promosi pada toko bagian luar Laundry.

c) Menambahkan armada layanan take and delivery.

d) Mengadakan pelatihan etika.

e) Mengadakan Laundry operational training kepada karyawan baru

f) Menambahkan layanan berbasis media sosial (WhatsApp, Line). 
g) Menentapkan jadwal pengambilan dan pengiriman.

h) Meningkatkan kepedulian kepada pelanggan.

i) Memberikan pelayanan gratis sebanyak 2 kali transaksi jika terjadi kehilangan.

j) Mengevaluasi keinginan pelanggan.

k) Buka dan tutup sesuai dengan jadwal yang telah ditetapkan.

1) Mengadakan training communication skills.

3. Penilaian pelanggan terhadap pemenuhan karakteristik kebutuhan dan keinginan pelanggan yang diberikan oleh Modern Laundry dan pesaingnya yaitu Laundry Kompetitor adalah sebagai berikut:

a) Karakteristik kebutuhan dan keinginan pelanggan Modern Laundry yang kurang unggul jika dibandingkan dengan laundry kompetitornya, dimana Laundry competitor tersebut memiliki gedung yang terlihat menarik dari luar, karyawan selalu siap dalam merespon permintaan pelanggan, pihak Laundry memiliki armada yang memadai dalam take and delivery pakaian, pakaian yang telah disetrika selalu tampak rapih, pihak Laundry akurat dalam mengidentifikasi noda pada pakaian (setiap noda yang ada dipakaian akan hilang), dan pihak Laundry selalu menanyakan apakah hasil pakaian yang sudah dicuci sudah sesuai belum wanginya.

b) Beberapa karakteristik kebutuhan dan keinginan pelanggan Modern Laundry yang setara atau harus dipertahankan adalah karyawan Laundry berseragam kerja, lama pengerjaan sesuai dengan waktu yang telah disepakati sebelumnya, pihak Laundry cepat dalam menangani transaksi pengambilan dan pengiriman pakaian, pihak Laundry menawarkan

bantuan kepada pelanggan, adanya jaminan ganti rugi kehilangan dari pihak Laundry, dan pihak Laundry memiliki karyawan yang pandai dalam berkomunikasi (tidak terjadi miskomunikasi).

c) Beberapa karakteristik kebutuhan dan keinginan pelanggan Modern Laundry yang lebih unggul dari kompetitornya adalah pihak Laundry memiliki karyawan yang dapat dipercaya (jujur), dan Laundry memiliki jam operasional yang tepat waktu.

4. Karakteristik kualitas pelayanan yang perlu ditingkatkan oleh Modern Laundry diantaranya:

a) Pakaian yang telah di setrika selalu tampak rapi.

Karakteristik tersebut harus ditingkatkan oleh pihak Modern Laundry mengingat karakteristik tersebut memiliki bobot absolut tertinggi.

b) Pihak laundry memiliki karyawan yang memiliki pengetahuan yang luas.

Karakteristik tersebut harus ditingkatkan oleh pihak Modern Laundry mengingat karakteristik tersebut memiliki bobot absolut tertinggi kedua.

\section{SARAN}

Dalam penelitian ini akan diberikan beberapa masukan atau saran kepada pihak Modern Laundry dan pihak lainnya mengenai hasil penelitian dengan metode QFD (Quality Function Deployment). Adapun saran tersebut adalah sebagai berikut:

1. Bagi Pihak Modern Laundry, perusahaan dapat menggunakan hasil penelitian ini sebagai masukan dan pertimbangan dalam upaya peningkatan kualitas pelayanan. Dalam penelitian ini Modern Laundry dapat melihat hal-hal apa saja

yang paling dibutuhkan oleh pelanggan dan dapat mengetahui hal-hal apa saja yang harus diprioritaskan dalam melakukan perbaikan sehingga kualitas pelayanan Modern Laundry dapat ditingkatkan, dan pelanggan Modern Laundry dapat meningkat setelah dilakukannya peningkatan kualitas pelayanan dengan QFD (Quality Function Deployment).

2. Bagi Akademisi hasil penelitian ini diharapkan dapat menjadi rujukan untuk penelitian berikutnya yang menggunakan metode QFD (Quality Function Deployment) dan dapat mengembangkan penelitian berikutnya dengan mengimplementasikan metode QFD di berbagai bidang lainnya, seperti manufaktur. 


\section{DAFTAR PUSTAKA}

Cohen, L. (2010). Quality Function Deployment: How to make QFD work of you. New York: Wesley Publishing Company.

Dharmawan, A., \& Wurjaningrum, F. (2014). Rancangan Perbaikan Kualitas Pelayanan Jasa Dengan Metode SERVQUAL, Importance Performance Analysis, Dan Quality Function Deployment Pada Plasa Telkom Cabang Dinoyo Surabaya. Jurnal Manajemen Teori dan Terapan, 211.

Heizer, J., \& Render, B. (2014). Operations Management: Sustainability and Supply Chain Management. Jakarta Selatan: Salemba Empat.

Heizer, J., Render, B., \& Munson, C. (2017). Operation Management. Sustainability and Supply Chain Management. United States of America: Pearson.

Kotler. (2013). In E. M. Sangadji, \& Sopiah, Perilaku Konsumen (p. 94). Yogyakarta: C.V ANDI OFFSET. Krajewski, L., Ritzman, L., \& Malhotra, M. (2010). Operations Management. New Jersey: Prentice Hall, Inc.

Parasuraman. (2013). In E. M. Sangadji, \& Sopiah, Perilaku Konsumen (p. 100). Yogyakarta: C.V ANDI OFFSET.

Sekaran, U. (2010). Research Method for Business: A Skill Building Approach. New Jersey: John Willey and Sons, inc.

Tjiptono, F., \& Chandra, G. (2016). Service, Quality dan Satisfaction. Yogyakarta: Andi Offset. 